\title{
Ethical Brand Image \& Corporate Goodwill: Issues \& Challenges
}

\author{
Dr. Jaskaran Singh Dhillon, Director \\ Swift Institute of Management and Computer Science \\ Swift Technical Campus, Rajpura \\ Patiala, Punjab, India
}

\begin{abstract}
This paper explores the concept of ethical branding and its link to corporate goodwill. Brands have traditionally been studied only as an economic construct. Brands, as a social construct, have not yet been fully understood due to the lack of research. A corporate brand is a vital part of the corporate goodwill management. An ethical brand enhances the firm's goodwill; such goodwill reinforces the brand in turn. On the other hand, any unethical behaviour will severely damage or even destroy the total intangible asset as evidenced by the recent high profile corporate scandals. Ethical branding could provide the company with a differential advantage as a growing number of consumers become more ethically conscious.
\end{abstract}

KEYWORDS: Brand Image, Ethics, Firms Goodwill, Corporate Social Responsibility

\section{INTRODUCTION}

There has been a growing research interest in the area of business and marketing ethics. Ethics has been studied in almost all business issues except branding. Not a single academic study has been found on branding ethics after an extensive literature search covering the following sources: three online database (ABI Inform Global, Ebsco and Infotrac), three journals (Journal of Business Ethics, Journal of Brand Management and Journal of Product and Brand Management), dozens of books and websites.

Brands may have been in existence for well over a thousand years. But never has any society before seen the power of branding as is witnessed today: Brands are prevalent in every aspect of human life: production and consumption, food and clothing, personality and lifestyle; and from pop culture to politics. Branding is no longer just about adding value to a product; branding represents and promotes lifestyles and brands themselves become a kind of culture. In the words of Hazel Kahan (quoted in Hall, 1999), brands are now gunning for a share of consumers' inner lives, their values, their beliefs, their politics; yes, their souls. The impact of brands and branding is far beyond the field of marketing and advertising. Branding is a social construct as well as an economic construct. As an economic construct, brands have been studied from both marketing and financial perspectives. As a social construct, brands have not yet been fully understood owing to the dearth of academic research in this area.

Advertising is probably the most visible element of marketing but branding is at the centre of any marketing communications. Most problems with advertising have their roots in branding strategy. A notorious example is Benetton's shocking tactic advertising in the 1990s. However, little is known about the impact of branding (not advertising) on the stakeholders other than brand owners and users, and about the link between branding and corporate goodwill. This paper aims to raise the awareness of ethical issues in corporate branding.

\section{WHAT IS ETHICAL BRANDING?}

Brand is a simple but very confused word with multiple meanings. The American Marketing Association defines a brand as: a name, term, sign, symbol, or design, or a combination of them, intended to identify the goods or services of one seller or group of sellers and differentiate them from those of competitors (Kotler, 2003). A brand 
may have many other meanings depending on the role it plays, the value it has and more importantly, to whom it is related. To brand owners, a brand is mainly a differentiation device: the living memory and the future of its products (Kapferer, 1997). To brand users, a brand may create an emotional bond with them which turns the brand into an icon. In the most developed role, brands represent not only the products or services a company provides but the firm itself, the brand is the company and brands become a synonym of the company's policy (Goodyear 1996; de Chernatony and McDonald, 2003). A brand is no longer just the interface between the company and its customers; to whom and to the general public, it is the face of the company.

Branding is a key function in marketing that means much more than just giving a product a name. Branding at corporate level is essentially about developing and managing the relationship between the organisation and its various stakeholders as well as the general public. Should branding be ethical? It might seem that the answer is obvious: most companies would answer yes. However, it would be more difficult to find a universal agreement on what ethical branding is. Ethics refers to moral rules or principles of behaviour for deciding what is right and wrong. These principles are not always easy to define as a) it is often difficult to distinguish between ethics and legality; b) ethical values vary between individuals and organisations, and between different cultures; and they are changing over time. Ethics is a very complex subject.

Marketing ethics is but a subset of business ethics which itself is a subset of ethics (Martin, 1985). Research on marketing ethics has so far been confined to general marketing issues, such as product safety, pricing, advertising and marketing research (Laczniak, 1993; Simith, 1995 and Murphy, 1999); little attention has been paid to branding. No business ethics books have been found to have reference to branding while leading branding texts have made no reference to ethics (Aaker, 1991; Kapferer, 1997; Keller, 1998 and de Chernatony and McDonald, 2003). A brand may be amoral, but there are ethical issues in branding. Ethical branding, as a subset of ethical marketing, relates to certain moral principles that define right and wrong behaviour in branding decisions. A brand needs to be evaluated not just by the economic or financial criteria but also by the moral ones. An ethical brand should not harm public good; instead it should contribute to or help promote public good.

\section{UNDERSTANDING BRANDING OBJECTIVES}

With the continuous advancement of technology, most consumer products have become a kind of commodity, i.e. there are fewer and fewer genuine and tangible differences between competing offers. The Unique Selling Proposition (USP) is no longer valid and being replaced by so called the Emotional Selling Proposition (Aitchison, 1999:42). This provides brand advertisers with a powerful tool to manipulate the consumer's emotion in order to achieve brand differentiation. The conventional wisdom of branding believes that the ultimate aim of branding is to command a favourable position in the mind of consumers, distinct from competition (Ries and Trout, 1982). A successful brand is believed to bring its owner great financial value in terms of either higher sales or premium prices. The ultimate objectives in branding can be summarised as follows:

- To dominate the market (to reduce or eliminate competition)

- To increase customer loyalty (by increasing the switch cost)

- To raise the entry barriers (to fend off potential threat)

These branding objectives could be ethically questionable under scrutiny. Whilst there may be nothing wrong if one brand succeeds in dominating the market, it is a different matter if the brand aims at monopoly with active attempt to eliminate competition as in the recent case of Microsoft, which was imposed a record $€ 497$ million fine by the EU for anti-competitive behaviour. As a human activity branding should be evaluated from a moral point of view. In the ruthless competition for market shares moral issues are probably the last concern for companies. The paradox is that the more successful a brand is in the marketplace, the more 
likely its branding strategy may become ethically questionable. Consider the following cases:

- Targeting at children as young as five years old who are impressionable;

- Alcoholic soft drink advertising encouraging under-age drinking;

- Exaggerating non-existing benefits in a basically commodity product;

- False and misleading advertising;

- Promoting self-indulgence and conspicuous consumption (e.g. binge drinking and consumer debts)

\section{A VULNERABLE ASSET}

The image of a brand can also be affected by nonbranding decisions that are made at the marketing or business level, for example, sweatshop accusations, animal testing, labour disputes, etc. Most business decisions that might eventually affect the organisation's brand image are made by people other than the brand manager on financial criteria with little consideration for ethical issues. Whenever anything goes wrong, be it a small incident or a big crisis, it is the brand that takes the blame; the brand image and corporate goodwill are always the victim. Brands became the mistaken identity in the debate between No Logo and Pro Logo camps (The Economist, 08/09/2001), as it is not the brand or logo, but the bad corporate policies that are responsible for all the wrongdoings. "Brands are not guilty of social and environmental damage - nor are they even a symbol of unethical working practice Corporations are guilty and laws that allow unethical practice are guilty" (anonymous comment on brandchannel.com 29/10/2001). Enron's downfall was not caused by the branding but the corrupted top management. A brand simply becomes the easy target or scapegoat for corporate misbehaviour. A brand is widely regarded as the most valuable asset an organisation has. An often-overlooked fact is that it is also the most vulnerable asset as well. A brand goodwill established with millions pounds of investment over many years could be easily damaged or even destroyed overnight.

\section{THE MULTIPLE IMAGES OF A BRAND}

A brand owner might want create one single image for its brand that is positive and consistent. In reality a brand may simultaneously hold multiple images - external versus internal, intended versus perceived and positive to neutral to negative, depending on that who interprets these images. Consider the case of Coca Cola.

Officially, the world's most valuable brand worth of $\$ 68.9 \mathrm{bn}$ wants to promote itself as the following: through our actions as local citizens, we strive every day to refresh the marketplace, enrich the workplace, preserve the environment and strengthen our communities (cocacola.com). However, behind this seemingly noble statement, there is another Coca Cola whose aim, according to its former senior vice chairman, was to encourage as many people as possible to drink as much Coca Cola as possible at the highest possible price so that the company could make even more money (Zyman, 1992). What a sharp contrast between the words and the deeds. It is not uncommon to find such a great discrepancy in other well-known brands such as Nike and McDonalds. Another example is the fashion retailer French Connection. The firm's fortune changed when it re-branded itself as FCUK, deliberately provoking outrage through its association with the F-word. Is this clever or irresponsible branding? As many people in marketing still believe that "ethics does not sell" and or that such concerns are outside their responsibility, managers will continue to face the dilemma of cost versus conscience. This is reflected in a statement made by Enron's former CEO Jeffery Skilling who reputedly said my job as a businessman is to maximise returns to shareholders. It is the government's job to step in if the product is dangerous (The Observer, 28/07/2002). This has echoed with Friedman's influential yet largely outdated view that the social responsibility of business is to increase its profits (1970).

There could also be a gap in the brand images projected by product and corporate advertising. Brand communications aimed at one group of 
audience may not be appreciated (or would even be misinterpreted) by another. There is an inherent problem here. It is impossible for a brand with a single image to appeal to everyone. If a brand appeals to one group audience it may also alienate or even offend other groups. Does it matter?

\section{DEFICIENCY IN BRAND MODELS}

The main attention of brand management in the last 20 years has been largely confined to product branding while corporate branding has been overlooked. This is particularly true in the fast moving consumer goods sector, and is also reflected in the branding models and research. In the conventional brand models (Aaker, 1991; Kapferer, 1997 and Keller, 1997), the brand is related to only two types of audiences: brand owner and brand user. The value of brand equity is defined and measured by its economic performance in financial terms. This model, albeit useful in explaining the so-called brand power, has a number of deficiencies. Firstly, two basic elements are missing: legality and ethics, which form the foundation of brand equity. A good brand must be a legal as well as ethical one. Thus brand value needs to be assessed by both financial and ethical measures. Secondly, conventional brand models focus largely on product brands rather than corporate brands. Brands and branding have such a profound impact on the society as whole and not just on these people who buy them. There is a wider public, in addition to shareholders and consumers, who may be potentially affected by the branding decisions: employees, suppliers, and the wider community. Brands that satisfy one group may affect another negatively. The impact of branding on these stakeholders should also be taken into consideration. A good brand is said to create financial value for its owner and emotional value for its users. What does a brand mean to the general public? Is it right that the interest of some stakeholders (brand owners and buyers) always outweigh the interest of other stakeholders? If a brand is studied in a broader social context, should it also bring public good to the society by symbolising some basic human (moral) values, or is that asking too much?

\section{CORPORATE ENTITY \\ BRAND}

While the primary purpose of product branding is to aid sales and profitability, the primary purpose of corporate branding is to embody the value system of the company and to help promote and enhance corporate goodwill. Corporate brand equity relates to the attitudes and associations that wide stakeholders have of a company as opposed to those of an individual product (Larkin, 2003). A brand cannot be separated from the organisational context in which it was created or is developed and managed (Feldwick, 1996). Thus it can be argued that there is a link between brand values and an organisation's corporate culture and/or mission statement. The recent fashion in branding is internal branding which believes that if employees fully understand and appreciate their brand they will be better able to provide the desired brand experience to consumers (Ind, 2001; Kunde and Cunningham, 2002). The brand can't just be a unique selling proposition. It has to be an "organising principle", uniting and directing the entire corporation. Employees can't just do a good day's work any more. They have to "live the brand" (Mitchell, 2001). However, this begs the question: does a brand have the same meaning to the management and employees as it has to the buyers? A brand is about the two key relationships: the relationship between the organisation and its customers, and the relationship between the organisation and other stakeholders and general public. The economic basis of a brand is that it should keep its promise of providing both physical and emotional benefits to its buyers.

Similarly, the social basis of a brand is that it must stick to its core values: trust, honesty, and integrity. Like any other long-term relationship, a brand must be developed and maintained on the basis of trust. Once the trust is lost or destroyed by any corporate wrongdoing the brand is doomed to fail as evidenced by some biggest corporate scandals in the USA and Europe. If marketing is, like some researchers (Vitell and Grove, 1987; 
Dunfee, et al, 1999) believe, the most prone to unethical behaviour due to its inherent attributes then branding must share some of the blame.

\section{BRANDING CORPORATE SOCIAL RESPONSIBILITY (CSR)}

Corporate social responsibility (CSR) and business ethics are the two concepts that are often used inter-exchangeably but different. This area is further complicated by the use of other terms such as corporate goodwill, corporate image, and corporate citizenship, to name but a few (for a comprehensive review on CSR, see Carroll, (1999)). According to Robin and Reidenbach (1987), CSR is related to the social contract between business and society in which it operates, while business ethics requires organisations to behave in accordance with carefully thought-out rules or moral philosophy. Socially "responsible" behaviour may be ethically neutral or even ethically unsound while actions dictated by moral philosophy may be socially unacceptable.

To its critics CSR is all about cover up and spin. Many companies used CSR as a kind of corporate PR rather than as genuine attempt to change the way they interact with society (WARC, 2003). When CSR is driven only by risk management it is not only fake and unsustainable, but also doomed to failure on its own term (Kitchin, 2003). Instead of addressing real issues, CSR merely stages an elaborate pantomime to conceal or distract public attention away from the corporate illness. CSR never tells the audience what happened behind the scene, i.e. what is really going on inside the company. The greatest CSR show in recent years was put on by Enron: before its demise Enron had been on the list of the 100 Best Companies to Work for in America and received six environmental awards in 2000. It issued a triple bottom line report. It had great policies on climate change, human rights, and (yes indeed) anti-corruption. Its $\mathrm{CEO}$ gave speeches at ethics conferences and put together a statement of values emphasising "communication, respect, and integrity." The company's stock was in many social investing mutual funds when it went down (Kelly, 2002).

\section{CAUSE MARKETING LATEST FAD.}

RELATED (CRM):

The idea behind CRM is that aligning companies with causes that consumers feel strongly about, will create social capital and there will be a strong association between consumers and companies (Dowling, 2001). As most marketing managers do not have adequate training or competence to decide which social cause to support and which to ignore, CRM is opportunistic and superficial at best. At worst it could bring in more trouble than benefit to the organisation as it risks alienating a large proportion of its potential consumers by taking stands on issues that are either controversial or have little to do with its core business, a good example is provided by Benetton's so-called social issue advertising.

\section{ETHICAL BRANDING AND CORPORATE GOODWILL}

Corporate goodwill can be defined in terms of a number of attributes that form a buyer's perception as to whether a company is well known, good or bad, reliable, trustworthy, reputable and believable (Levitt, 1965). Corporate goodwill is concerned with how people feel about a company based on whatever information (or misinformation) they have on, company activities, workplace, past performance and future prospects (Fombrun, 2000). According to Keller (1998), a socially responsible corporate image association involves the creation of consumer perceptions of a company as contributing to community programs, supporting artistic and social

activities and generally attempting to improve the welfare of society as a whole.

A corporate brand is the core component of corporate goodwill. Being the face of the organisation that owns it, a corporate brand has to communicate to a wider range of audiences than consumers and investors. There is an interesting 
relationship between corporate goodwill and corporate performance. Corporate goodwill is believed to have positive impact on a firm's market share and ultimately on the stock market value. According to one study of long-term stock price movements and company goodwill changes, some $8-15 \%$ of a company's stock price can be accounted for by corporate goodwill (Greyser, 1996). On the other hand, a company's corporate goodwill is also affected by its past performance, both financial performance and social performance.

Clearly there is a close link between ethical branding and corporate goodwill. These attributes may include: honesty, integrity, diversity, quality, respect, responsibility and accountability (cocacola.com), and define what an ethical brand stands for. An ethical brand enhances the firm's goodwill; such a goodwill reinforces the brand in turn. Ethical branding can be studied at both corporate and product levels. At the corporate level, a corporate brand is a vital part of the corporate goodwill management. Any unethical behaviour will severely damage or even destroy the total intangible asset as evidenced by the some recent high profile scandals such as Enron and Anderson Consulting. Branding at the product level involves labelling, packaging and communicating. Although these do not have a direct impact upon the corporate brand, they can still affect the goodwill of the organisation. Some corporate PR activities such as sponsorship and donations will not automatically change the public opinion if the company is generally perceived as unethical and not genuine; for example, the sponsorship of a research centre for corporate responsibility by a tobacco firm. Corporate donations and CSR should not be used as varnish to cover corporate misbehaviour. The organisation needs to make systematic efforts to create and maintain an ethical corporate brand image that not only enhances its corporate goodwill but also gives the business competitive advantages.

\section{DOES THE CONSUMER REALLY CARE ABOUT BRANDING ETHICS?}

A popular or successful brand may not be ethical (it could be a controversial one, such as the chainsaw waving Eminem). On the other hand, ethical branding cannot guarantee a firm the success in the marketplace. Consumers generally do have ethical concerns but such concerns do not necessarily become manifest in their actual purchasing behaviour. So does ethical branding matter? The literature seems to be divided on the responses of consumers. One survey in the USA finds that ethical behaviour is an important consideration during the purchase decision and consumers are willing to pay higher prices for that firm's product (Creyer and Ross, 1997). A UK study concludes that although consumers are more sophisticated today, this does not necessarily translate into behaviour that favours ethical companies over unethical ones (Carrigan and Attalla, 2001). Another US study finds that today's consumers, facing more choices in the marketplace and changes in lifestyle, their sophistication is in decline rather than increase (Titus and Bradford, 1996). The consequence of this decline is unsophisticated consumers tend to reward unethical business practices and punish ethical business behaviour. As far as ethical branding is concerned, two questions need to be asked: Do the brand users care? Do the general public care?

Despite the conflicting findings in the literature, society today seems to be more concerned about ethical issues in marketing compared with 20 years ago. The more high-profile a brand is, the higher expectation in ethical behaviour the public would place upon the brand. As an increasing number of consumers become ethically conscious, they do take ethical issues in branding seriously. This will in turn force branding to become more ethically accountable.

\section{CONCLUSIONS}

Business is a human activity and, like most human activities, it has been and is likely to continue to be evaluated from a moral point of view (Robin and Reidenbach, 1987). Branding, as part of business, is no exception. There is still much confusion about whether a brand itself is unethical or whether something casts an unethical image on 
the brand. A brand is itself neither good nor bad. But the value a brand represents and branding decisions and practice, as a subset of marketing, can be ethical or unethical.

The age of differentiation in products or service is all but gone as there is virtually little difference between the competing offers. Consumers are well aware of this fact. A recent survey by the Marketing Forum /Consumer Association revealed a high degree of consumer scepticism and cynicism to branding. $78 \%$ consumers agreed with the statement that "Companies like to pretend their brands are really different, but actually there's rarely any substantial difference between them", while $76 \%$ agreed that many companies "see their brands as a way of pushing up prices" (Mitchell, 2001). Today's business organisations face the increasing pressure from two fronts:

- from shareholders the pressure to improve financial performance,

- from wide stakeholders to behave in a socially responsible way.

If corporate goodwill is a valuable intangible asset that needs to be actively managed in the boardroom (Larkin, 2003) rather than be passively defended or rescued when in crisis, ethics and social responsibility hold the key in corporate communications. Ethical corporate branding has a greater role to play in the corporate goodwill management. Corporate branding should provide a clear vision about how the firm's brands are going to make the world a better place and have a justified set of core values (de Chernatony and McDonald, 2003). This ethical brand positioning could benefit the company with a differential advantage over competition; and at the same time, could help overcome the increasing consumers' scepticism and cynicism towards branding communications.

Ethical branding is a new area with many complicated issues in need of research. These issues can be separated into two broad categories.

Firstly, ethical issues in the branding decisions: naming, renaming, positioning and targeting. Enough has been written about the purported benefits that a brand brings to the consumer and its owner (Ambler, 1997). Further research should ask new questions: What is ethical branding?
What criteria can be used to differentiate ethical branding from unethical branding? How does the company create and communicate an ethical brand? Does ethical branding affect consumers' purchasing decisions?

Secondly, at a philosophical level: the relationship between brand/branding and society needs to be examined. Is the goal of branding primarily and exclusively to enrich its shareholders? What is the social purpose of branding? What are its impact and consequences? Should a brand stand for some core human values? How does this fit with the social role or CSR of the business?

\section{REFERENCE}

[1] Aaker, D. (1991) Managing brand equity, Free Press

[2] Aitchison, J. (1999) Cutting edge advertising, Prentice Hall Singapore

[3] Ambler, T. (1997) "Do brands benefit consumers? International Journal of Advertising, 16, 167-198.

[4] Carroll, A. B. (1999) "Corporate social responsibility, Business and Society, 38:3, 268-295

[5] Carrigan, M and Attalla, A, (2001) The myth of the ethical consumer - do ethics matter in purchase behaviour? Journal of Consumer Marketing, 18:7, 560-77.

[6] Cryer, E H and Ross, W T (1997) The influence of firm behaviour on purchase intention: do consumers really care about business ethics? Journal of consumer Marketing, 14:6, 421-33

[7] De Chernatony L. and McDonald M. (2003) Creating Powerful Brands, 3/e Elsevier

[8] Dunfee, T. W., Smith, N. C. and Ross, W. T. (1999) "Social contracts and marketing ethics", Journal of Marketing, 63 July $14-32$

[9] Dowling, G. (2001) Creating corporate goodwills, Oxford University Press.

[10] Feldwick, P. (1996) "What is brand equity anyway, and how do you measure it?" Journal of the Market Research Society, 38:2, 85-104 
[11] Fombrun, C. (2000) "The value to be found in corporate goodwill", Financial Times, 4 December

[12] Friedman, M. (1970) "The social responsibility of business is to increase its profits", The New York Times Magazine, 13 Sept.

[13] Goodyear, M. (1996) "Divided by a common language", Journal of Market Research Society, 38:2, 110-22

[14] Greyser, S. (1996) "Corporate goodwill and the bottom line", speech at the launch of the International Corporate Identity Group, House of Lords, London

[15] Hall, J. (1999) "Corporate ethics and the new commercial paradigm”, Journal of Brand Management, 7:1 38-47

[16] Ind, N. (2001) Living the brand, Kogan Page.

[17] Kapferer, J. (1997) Strategic brand management, 2/e, Kogan Page

[18] Kapferer, J. (2001) Reinventing the brand, Kogan Page

[19] Keller, K. (1998) Strategic brand management, Prentice Hall

[20] Kelly, M. (2002) "The next step for CSR: building economic democracy", Business Ethics, Summer Issue.

[21] Kunde, J. and Cunningham, B. J. (2002) Corporate religion, FT Management.

[22] Laczniak, G. R. "Marketing ethics: onward toward greater expectations", Journal of Public Policy and Marketing, 12:1, 91-96.

[23] Larkin, J. (2003) Strategic Goodwill Risk Management, Palgrave MacMillian.

[24] Levitt, T (1965) Industrial Purchasing Behaviour: A study of communication effects. Harvard Business School, Boston, MA

[25] Kitchin, T. (2003) "Human structure: an oxymoron", mutualmarketing.co.uk, 07/10/03

[26] Martin, T. R. (1985) "Ethics in marketing: problems and prospects", in Laczniak, G. R. and Murphy. P. E. (Eds), Marketing Ethics: Guideline for Managers, Lexington Books, MA

[27] Mitchell, A. (2001) "Rethinking brand thinking: the emperor's new clothes- A backlash against branding?", Market Leader, Issue 15

[28] Murphy, P. E. (1999) "Ethics in advertising: review, analysis, and suggestions", Journal of Public Policy and Marketing, 17:2, 316-19.

[29] Ries, A. and Trout, J. (1982) Positioning: the battle for your mind, Warner, NY.

[30] Robin, D. P. and Reidenbach, R. E. (1987) "Social responsibility, ethics, and marketing strategy: closing the gap between concept and application", Journal of Marketing, 51, Jan., 44-58

[31] Smith, N. C. (1995) "Marketing strategies for the ethics era", Sloan Management Review, Summer 85-97

[32] Vitell, S. J. and Grove, S.J. (1987) "Marketing ethics and the techniques of neutralisation", Journal of Business Ethics, 6, 433-438

[33] WARC (2003) "Corporate social responsibility - how far should it go?" Hot Topics, November, www.warc.com/fulltext/hottopics/78289 .htm 